\title{
Penetapan Harga Jual Produk Murabahah Studi Kasus di BMT Rama Salatiga
}

Arna Asna Annisa

Sekolah Tinggi Agama Islam Negeri (STAIN) Salatiga

arnaannisa@gmail.com

\begin{abstract}
This thesis is entitled Selling Price Regulation of Murabahah Product Case Study: BMT RAMA Salatiga. The objectives of this research are to describe 1) the execution of murabahah transaction at BMT RAMA Salatiga, 2) the method in deciding and applying the selling price of murabahah product, and 3) the policy of BMT on conducting its business based on Islamic principles. This research applied descriptive qualitative design and was conducted based on normative-juridical approach. The subjects of the research were the manager of BMT RAMA Salatiga and the costumers of BMT RAMA who were involved in murabahah transactions. The results show that the execution of murabahah transaction has not been applied well. Basically, wakalah aqad should place the costumer as the representative of BMT to get goods before the aqad is signed. It is applied in order to prevent gharar and to draw a distinction between syariah and conventional banking. In regulating its funding product BMT RAMA considers some components such as risks of fund, cost of fund, operational cost, annual profit target, annual funding target, and competition rates. However, the cost of fund component has the consequence of interests which need to be considered in determining murabahah margin. This consequence is absolutely inapropriate with MUI instruction no. 1 year 2004, which forbids interests because of its belonging to riba. Unfortunately, the DPS assistance is still insufficient on this matter.
\end{abstract}

Keywords: BMT, murabahah, price of sale, interest

\begin{abstract}
Abstrak:
Penelitian dalam tesis ini bertujuan untuk mendeskripsikan pelaksanaan transaksi produk murabahah di BMT RAMA Salatiga, metode penentuan dan penerapan harga jual produk murabahah, serta kebijakan BMT dalam menjalankan usahanya agar sesuai syariah. Penelitian ini menggunakan desain kualitatif dan bersifat deskriptif. Sedangkan pendekatan yang digunakan adalah yuridis-normatif. Subjek dalam penelitian ini adalah manajer BMT RAMA Salatiga dan nasabah pembiayaan murabahah yang menggunakan produk ini di BMT RAMA. Hasil penelitian menunjukkan bahwa pelaksanaan transaksi murabahah belum dilaksanakan sebagaimana mestinya. Akad wakalah yang digunakan BMT seharusnya menempatkan nasabah sebagai wakil BMT untuk mendapatkan barang, baru kemudian akad ditandatangani. Hal ini untuk menghindari jual beli gharar dan proses inilah yang seharusnya membedakan dengan transaksi kredit di bank konvensional. Dalam penetapan harga jualnya, BMT RAMA menggunakan komponen resiko pembiayaan, cost of fund, biaya operasional, target laba tahun ini, target pembiayaan tahun ini, dan posisi persaingan. Penggunaan komponen cost of fund berdampak pada bunga yang harus turut dipertimbangkan dalam marjin murabahah.
\end{abstract}


Hal ini jelas menyalahi aturan dalam fatwa MUI No. 1 tahun 2004 yang telah mengharamkan bunga karena termasuk riba. Sedangkan pengawasan dari DPS sendiri pun masih sangat lemah.

Kata Kunci: BMT, murabahah, harga jual, bunga

\section{Pendahuluan}

Perkembangan ekonomi Islam identik dengan berkembangnya lembaga keuangan syariah. Seiring dengan hal tersebut, lembaga keuangan syariah yang ruang lingkupnya mikro yaitu Baitul māl wattamwil (BMT) juga semakin menunjukkan eksistensinya.

Seperti halnya bank syariah, kegiatan BMT adalah melakukan penghimpunan (prinsip wadhiah dan mudharabah) dan penyaluran dana (prinsip bagi hasil, jual beli dan ijarah) kepada masyarakat (Kusmiyati, 2007: 28). Penyaluran dana dengan prinsip jual beli dilakukan dengan akad murabahah, salam, ataupun istishna. Sedangkan murabahah sendiri merupakan akad yang paling dominan digunakan dalam transaksi jual beli.Dari beberapa hasil survey menunjukkan bahwa bank syariah menerapkan produk murabahah kurang lebih tujuh puluh lima persen (75\%) dari total kekayaan mereka. Islamic Development Bank (IDB) sendiri selama lebih dari sepuluh tahun periode pembiayaan, tujuh puluh tiga persen $(73 \%)$ dari seluruh pembiayaannya adalah murabahah (Rahmawaty, 2007: 188-189).

Menurut Choudury, dominannya pembiayaan murabahah terjadi karena pembiayaan ini memiliki kecenderungan risiko yang lebih kecil dan lebih mengamankan bagi shareholder (Kusmiyati: 2007, 28). Namun begitu, mekanisme pembiayaan murabahah ini bukannya tanpa kritikan. Abdullah Saeed melontarkan kritik terhadap murabahah bahwa justru dari sudut pandang ekoonomi, memang tidak ada perbedaan yang mendasar antara mark up dengan bunga. Perbedaan keduanya hanyalah menyangkut soal hukum antara kontrak hutang piutang dalam bunga dan kontrak jual beli dalam mark up.Siddiqi dalam karyanya Banking Without Interest dengan tegas menyatakan untuk menghapus instrument murabahah dari perbankan syariah (Rahmawaty, 2007: 193).

Kondisi tersebut dapat terlihat dalam penentuan harga jual produk murabahah. Hal ini didasarkan pada kenyataan bahwa lembaga keuangan syariah yang menggunakan akad murabahah dalam menjual barang, tetap menggunakan prinsip cost of fund yang merupakan landasan kekejaman kredit dalam perbankan konvensional. Pada proses penentuan harga jualnya, bank syariah masih bergantung kepada beberapa faktor layaknya bank konvensional, yaitu suku 
bunga yang dikeluarkan oleh Bank Indonesia, dan pemindahan beban keuntungan bagi pihak bank, pemilik modal, serta nasabah penyimpan (Abduh, 2011).

Kecenderungan yang sama terjadi pada BMT. Lingkup usaha yang mikro, menjadikan BMT mesti eksis sebagai sebuah industri. Sedangkan dalam tubuh BMT sendiri telah melekat prinsip-prinsip syariah yang harus dijalankan. Dalam Undang-Undang Nomor 10 tahun 1998 pasal 1 ayat (3) dalam Lembaran Negara Republik Indonesia Tahun 1998 Nomor 182, dijelaskan bahwa,

Prinsip syariah adalah aturan perjanjian berdasarkan hukum Islam antara bank dengan pihak lain untuk penyimpanan dana dan atau pembiayaan kegiatan usaha atau kegiatan lainnya yang dinyatakan sesuai dengan syariah, antara lain pembiayaan dengan prinsip bagi hasil (mudarabah), pembiayaan berdasarkan prinsip penyertaan modal (musyarakah), prinsip jual beli barang dengan keuntungan (murabahah) atau pembiayaan barang modal berdasarkan prinsip sewa murni tanpa pilihan (ijarah), atau dengan adanya pilihan pemindahan kepemilikan atas barang yang disewa dari pihak bank oleh piha lain (ijarah wa iqtina).

BMT RAMA sendiri merupakan Koperasi Simpan Pinjam Syariah (KSPS) yang terletak di jantung kota salatiga, lokasinya yang tepat ditengah pasar membuat BMT ini dekat dengan nasabah dengan latar belakang pedagang yang notabene mereka juga dekat dengan lembaga keuangan yang menggunakan bunga sebagai persyaratan permodalan.

Berangkat dari realitas penyaluran dana khususnya produk pembiayaan murabahah sebagaimana tersebut diatas, kiranya cukup menarik untuk dikaji dan dianalisa praktik penetapan harga jual produk murabahah di BMT RAMA Salatiga.

\section{Rumusan Masalah}

Berdasarkan uraian yang telah dipaparkan diatas, persoalan yang akan dibahas dalam penelitian ini yaitu: 1) Bagaimana pelaksanaan transaksi produk murabahah pada BMT RAMA Salatiga; 2) Bagaimana metode dan penerapan penentuan harga jual produk murabahah di BMT RAMA Salatiga ditinjau dari pinsip syariah; 3) Bagaimana kebijakan BMT RAMA Salatiga untuk menjalankan usahanya dalam tinjauan syariah.

\section{Tujuan}

Penelitian ini dilakukan dengan maksud dan tujuan untuk menjelaskan sekaligus menganalisis transaksi produk murabahah di BMT RAMA Salatiga dalam hal sebagai berikut: 1) 
Praktik transaksi pembiayaan murabahah pada BMT RAMA Salatiga; 2) Metode dan penerapan penentuan harga jual produk murabahah yang di BMT RAMA Salatiga ditinjau dari prinsip syariah; 3) Kebijakan BMT RAMA Salatiga untuk menjalankan usahanya dalam tinjauan syariah.

\section{Studi Pustaka dan Kerangka Teoritik}

Terdapat beberapa tulisan yang mengupas tentang sistem perbankan yang masih belum bebas dari bunga, seperti Firmansyah dalam penelitiannya yang berjudul "Evaluasi Metode Penentuan Harga Jual Beli Murabahah di BMT Berkah Madani”mengupas tentang bagaimana kebijakan penentuan harga jual beli murabahah yang dilakukan BMT Berkah Madani. Dalam penelitian yang menggunakan metode deskriptif ini, diamenemukan bahwa dalam penentuan harga jual produk murabahah, BMT masih menyandarkannya pada suku bunga yang berlaku di pasar dan beban bagi hasil dengan pemilik saham dan nasabah penyimpan (Firmansyah, 2007).

Wildan Tojibi yang melakukan penelitian dengan judul "Tinjauan Yuridis terhadap Transaksi Murabahah pada Bank Muamalat Indonesia Cabang Yogyakarta” mengungkapkan bahwa transaksi murabahah yang disertai wakalah pada BMI cabang Yogyakarta belum sesuai dengan prinsip syariah karena ketika akad dilaksanakan, barang belum menjadi milik bank. Sedangkan dalam penyelesaian sengketa, BMI lebih mengedepankan penyelesaian sengketa non litigasi melalui BASYARNAS (Tojibi, 2007).

Murabahah dalam perspektif fikih dan sistem perbankan Islam telah dikupas oleh Ubay Harun. Dalam kesimpulannya, dijelaskan bahwa murabahah merupakan salah satu bentuk bai' al amanah dan bai' at-tauliyyah, yakni menjual barang dengan harga pokok tanpa mengambil keuntungan apapun, serta bai' al wadi'ah, yaitu menjual barang dengan harga jual dibawah harga pokok. Penerapan murabahah dalam perbankan syariah diartikan sebagai akad jual beli antara bank selaku penyedia barang dengan nasabah yang memesan barang, dan dari transaksi inilah bank mendapat keuntungan (Harun, 2006).

Jurnal internasional yang cukup menarik berjudul "An Economic Explication of the Prohibitin of Riba in Classical Islamic Jurisprudence” tulisan Mahmoud A. El Gamal mencoba mengupas tentang posisi bunga. Bahwasanya pembatasan riba tidak hanya tentang eksploitasi, bahwa bunga tidak semua riba, dan bahwa tidak semua riba itu adalah bunga. Adiwarman A Karim memunculkan karyanya yang diberi judul "Bank Islam Analisis Fikih dan Keuangan”, 
yang telah mengupas bagaimana hakekat dan filosofi dari pembentukan akad-akad syariah dengan mengemukakan teori pertukaran dan percampuran, suatu teori yang harus dipahami dengan baik, karena dari teori tersebut pembentukan dan pengembangan akad-akad syariah dilakukan, kemudian dijelaskan juga tentang produk dan jasa bank syariah, pembiayaan murabahah dan istisna', ijarah dan ijarah mumtahiya bit tamlik (IMBT) serta mudharabah. Dia berkesimpulan bahwa jual beli murabahah adalah merupakan akad jual beli barang dengan menyatakan harga perolehan dan keuntungan yang disepakati oleh penjual (dalam praktik perbankan adalah pihak bank) dan pembeli atau nasabah (Karim, 2006).

Dari uraian sebelumnya, dapatlah disusun kerangka teori dari penelitian ini sebagai berikut:

\section{a. Wacana BMT}

Pada awal konsepnya, BMT mempertegas ciri utamanya sebagai lembaga yang berorientasi bisnis dan bukan lembaga sosial. Akan tetapi ia bergerak juga untuk penyaluran dan penggunaan zakat, infaq, dan sadaqoh; ditumbuhkan dari bawah berlandaskan peran serta masyarakat disekitarnya, milik bersama masyarakat kecil-bawah dan kecil dari lingkungan BMT itu sendiri, bukan milik seseorang atau orang dari luar masyarakat itu. Peran umum BMT yang dilakukan adalah melakukan pembinaan dan pendanaan yang berdasarkan sistem syariah. Peran ini menegaskan arti penting prinsipprinsip syariah dalam kehidupan ekonomi masyarakat.

Pada awalnya BMT adalah sebuah organisasi informal dalam bentuk Kelompok Simpan Pinjam (KSP) atau Kelompok Swadaya Masyarakat (KSM) yaitu suatu lembaga yang melakukan penghimpunan dana dari anggota dan diperuntukkan bagi anggota. Oleh karenanya, maka BMT harus tunduk pada Undang-undang Nomor 25 tahun 1992 tentang Perkoperasian dan PP Nomor 9 tahun 1995 tentang pelaksanaan usaha simpan pinjam oleh koperasi (Madjid, 2000: 91). Juga dipertegas oleh KEP.MEN Nomor 91 tahun 2004 tentang Koperasi Jasa keuangan syariah. Undang-undang tersebut sebagai payung berdirinya BMT (Lembaga Keuangan Mikro Syariah).

Berbagai produk BMT bisa digambarkan melalui gambar berikut:

Gambar 1: Produk dalam Bank Syariah 


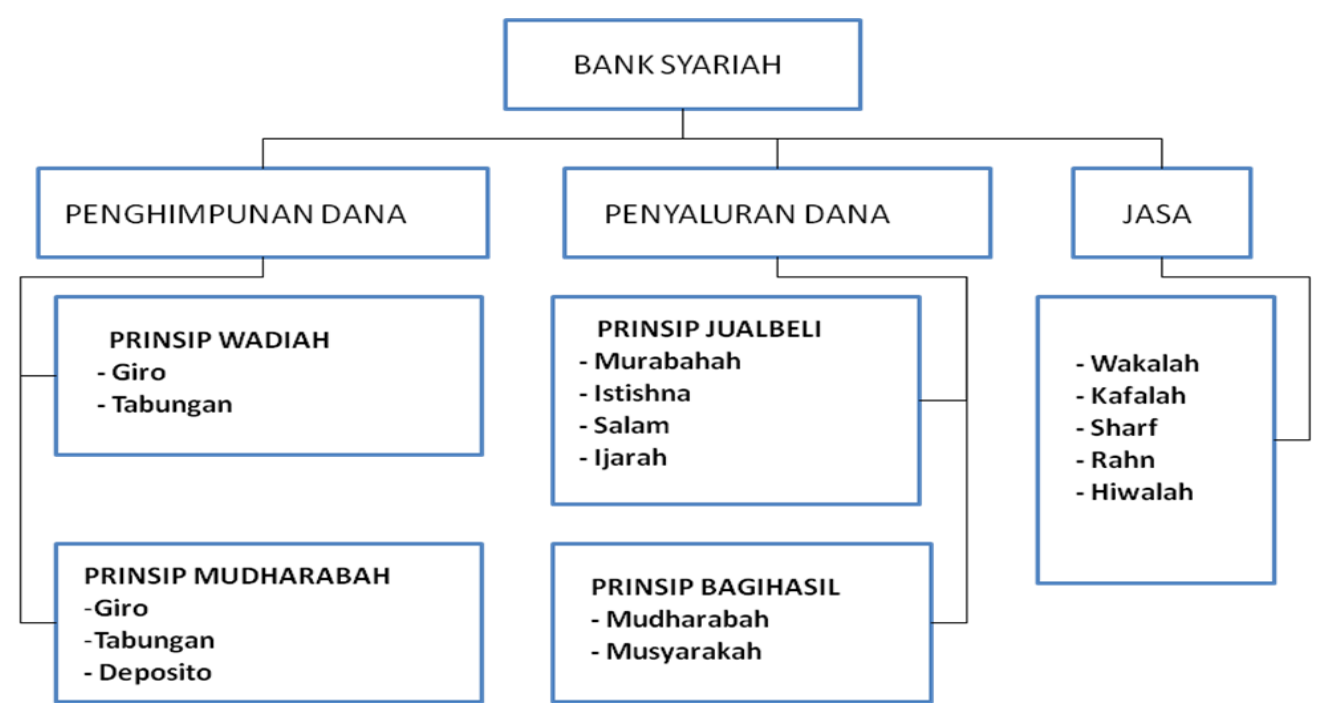

\section{b. Al Murabahah}

Menurut terminologi ilmu fikih, murabahah adalah menjual dengan modal asli bersama tambahan keuntungan yang jelas.Sedangkan dalam kamus istilah keuangan dan perbankan syariah yang diterbitkan oleh direktorat perbankan syariah, Bank Indonesia mengemukakan: bai murabahah (بيع العرابحة), jual beli barang pada harga asal dengan tambahan keuntungan yang disepakati (As Shawi, 2004: 198).

Al-Qur'an sebagai sumber hukum utama tidak pernah secara langsung membicarakan tentang murabahah, meski disana ada beberapa acuan tentang jual beli, laba, rugi, dan juga tentang perdagangan, diantaranya Q.S. Al Baqarah: 275 dan Q. S An Nisa: 29. Sedangkan Imam Malik dan Imam Syafi'i mengatakan bahwa jual beli murabahah itu sah menurut hukum walaupun Abdullah Saeed mengatakan bahwa pernyataan ini tidak menyebutkan referensi yang jelas dari hadis (Saeed, 2003).

Wahbah az-Zuhaili memberikan definisi murabahah yaitu

$$
\text { الييع بمثل الأول مع زيادة ربح }
$$

"Jual beli dengan harga awal ditambah keuntungan"

Wahbah az-Zuhaili mengatakan bahwa dalam jual beli murabahah itu disyaratkan beberapa hal, yaitu: 1) Mengetahui harga pokok; 2) Mengetahui keuntungan; 3) Harga 
pokok merupakan sesuatu yang dapat diukur, dihitung dan ditimbang, baik pada waktu terjadi jual beli dengan penjual yang pertama atau setelahnya (Az-Zuhaili, 2006: 345).

Dalam SOP KJKS, pembiayaan murabahah disebut sebagai piutang murabahah, yaitu tagihan atas transaksi penjualan barang dengan menyatakan harga perolehan dan keuntungan (marjin) yang disepakati oleh pihak penjual (koperasi) dan pembeli (anggota, calon anggota, koperasi lain, dan atau anggotanya) dan atas transaksi jual beli tersebut yang mewajibkan anggota untuk melunasi kewajibannya sesuai jangka waktu tertentu disertai dengan pembayaran imbalan berupa marjin keuntungan yang disepakati dimuka sesuai akad.

Gambar 2: Skema asli penyaluran danamurabahah

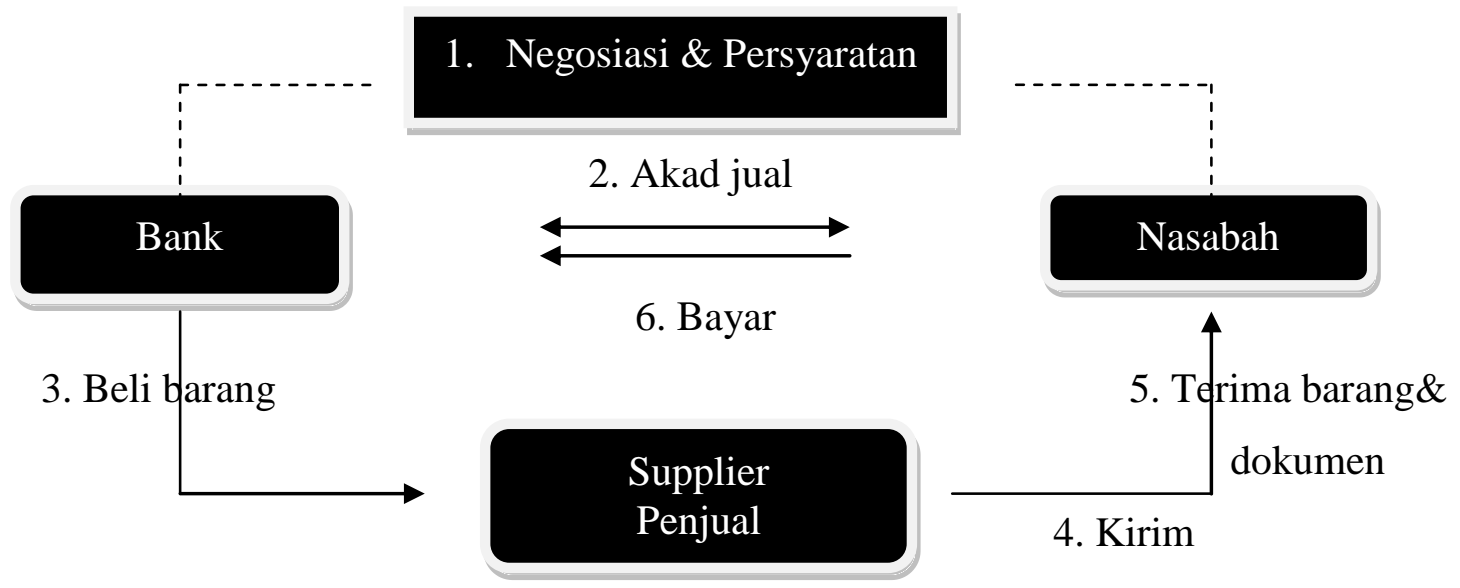

Sumber: Muhammad Syafi'i Antonio, 1999

Gambar 3: Skema pengembangan murabahah

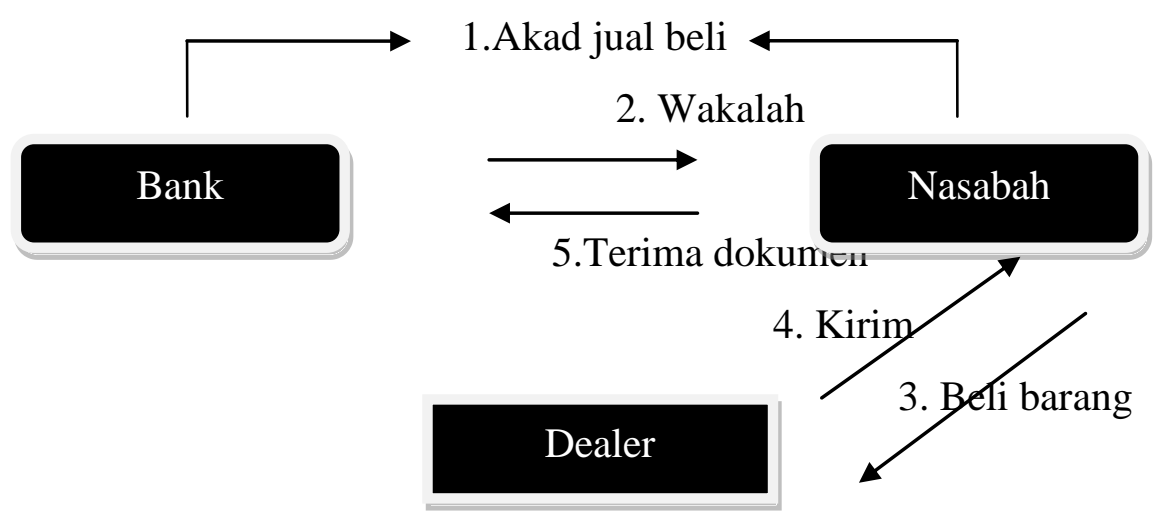

Sumber: Penjelasan Fatwa No. 04/DSN-MUI/IV/2000 
Secara teknis, beberapa landasan dalam operasional murabahah adalah sebagai berikut: 1) Musyawarah dan kesepakatan di mana masing-masing pihak memiliki hak dan kewajiban yang sama; 2) Jaminan. Hal ini diperlukan untuk memperkecil resiko yang merugikan pihak bank dan untuk melihat kemampuan nasabah dalam menanggung pembayaran kembali atas pembiayaan yang diterima dari bank; 3) Dokumentasi (Muhammad, 2009: 59-62).

Fatwa-fatwa yang berkaitan dengan murabahah yaitu: 1) Fatwa DSN No. 04/DSN-MUI/IV/2000, ketentuan tentang murabahah; 2) Fatwa DSN No. 13/DSNMUI/IX/2000 tentang uang muka murabahah; 3) Fatwa DSN No. 16/DSN-MUI/IX/2000; Diskon Murabahah; 4) Fatwa DSN No. 17/DSN-MUI/IX/2000 tentang sanksi atas nasabah mampu yang menunda-nunda pembayaran; 5) Fatwa DSN No. 23/DSNMUI/III/2002; Potongan pelunasan dalam murabahah; 6) Ketentuan ganti rugi (ta'widh) lihat halaman 22 PBI 7/46.

\section{c. Riba dan Bunga Bank}

Riba secara etimologi berarti زيادة (tambahan) kepada sesuatu, النمو (tumbuh dan berkembang). Pada dasarnya riba tidak bermakna negatif, akan tetapi seperti dalam maknanya yaitu tambahan secara mutlak. Dalam Al-Qur'an (Q.S Al Baqarah: 276), riba juga dipakai dalam shodaqoh (ويربى الصدقات), bahwa Allah menumbuhkembangkan shodaqoh. Jadi riba bisa bermakna positif dan atau negatif (Asymawi, 2009: 1).

Dalam pandangan fuqaha, riba merupakan kelebihan harta dalam suatu kegiatan muamalah dengan tidak ada imbalan atau gantinya.Artinya tambahan terhadap modal uang yang timbul akibat suatu transaksi utang piutang yang harus diberikan kepada pemilik uang pada saat utang jatuh tempo. Dan dalam Q.S. Al Baqarah: 275- 279. Allah s.w.t. tegas mengharamkan riba secara total dengan segala bentuk riba.

Menurut Muhammad, riba tergolong menjadi 3 yaitu sebagai berikut:

Tabel 1. Jenis-jenis Riba

\begin{tabular}{|c|c|c|}
\hline Tipe Riba & Faktor Penyebab & $\begin{array}{c}\text { Cara Menghilangkan } \\
\text { Faktor Penyebab }\end{array}$ \\
\hline
\end{tabular}




\begin{tabular}{|c|c|c|}
\hline Riba $f a d l$ & $\begin{array}{l}\text { Gharar (uncertain } \\
\text { to both parties) }\end{array}$ & $\begin{array}{l}\text { Kedua belah pihak harus } \\
\text { memastikan faktor berikut: 1) } \\
\text { kuantitas; 2) kualitas; 3) harga; 4) } \\
\text { waktu penyerahan }\end{array}$ \\
\hline Riba nasi'ah & $\begin{array}{l}\text { Return tanpa risiko, } \\
\text { pendapatan tanpa } \\
\text { biaya }\end{array}$ & $\begin{array}{l}\text { Kedua belah pihak membuat } \\
\text { kontrak yang merinci hak dan } \\
\text { kewajiban masing-masing untuk } \\
\text { menjamin tidak adanya pihak } \\
\text { manapun yang mendapatkan return } \\
\text { tanpa menanggung risiko, atau } \\
\text { menikmati pendapatan tanpa } \\
\text { menanggung biaya }\end{array}$ \\
\hline $\begin{array}{l}\text { Riba } \\
\text { jahiliyah }\end{array}$ & $\begin{array}{l}\text { Memberi pinjaman } \\
\text { sukarela secara } \\
\text { komersiil, karena } \\
\text { setiap pinjaman } \\
\text { yang mengambil } \\
\text { manfaat adalah riba }\end{array}$ & $\begin{array}{l}\text { Jangan mengambil manfaat apapun } \\
\text { dari akad kebaikan (tabarru') } \\
\text { Kalaupun ingin mengambil } \\
\text { manfaat maka gunakan akad bisnis } \\
\text { (tijarah), bukan akad kebaikan } \\
\text { (tabarru') }\end{array}$ \\
\hline
\end{tabular}

Sumber: Muhammad, 2011

Menilik pada bunga bank, bunga dalam bahasa Inggris disebut usury dan interest. Menurut pemikir Islam, usury adalah bunga yang dibayarkan terhadap pinjaman untuk kegiatan konsumsi, sedangkan interest adalah pinjaman untuk kegiatan produksi. Keduanya merupakan pinjaman dengan tambahan. Jadi pada hakekatnya interest dan usury merupakan dua konsep yang serupa, yaitu keuntungan yang diharapkan oleh pemberi pinjaman atas peminjaman uang atau barang (mutuum), yang sebenarnya barang atau uang tersebut apabila tidak ada unsur tenaga kerja tidak akan menghasilkan apa-apa. Jadi sekali lagi, usury muncul akibat proses peminjaman dan bukan akibat jual beli.

Apabila ditinjau dari segi fikih, menurut Qardhawi bunga bank sama dengan riba yang hukumnya jelas-jelas haram (Qardhawi, 1987). Dalam Q.S Al Kahfi: 23-24 dapat dijelaskan 
bahwa pemastian akan sesuatu hal itu dilarang. Dengan adanya praktik perbungaan dalam perbankan konvensional nampak jelas dari kacamata syariah bahwa hal itu haram hukumnya.

Dr. Mustafa Omar Mohammed dari IIUM dalam tulisannya di Republika menyatakan bahwa 'illah dalam hal pelarangan riba adalah perkara ats-Tsawabit dan al-Mutaghayyirat. Beliau mencoba mengkritisi tentang alasan bahwa riba dilarang karena sifat eksploitasinya. Bahwa ketika memang riba dilarang karena eksploitasi, maka baik itu persentasenya kecil atau besar harus konsisten dilarang (Mohammed, 2011: 24). Berikut gambaran skemanya:

Gambar 4: Benchmark untuk Menentukan 'Illah Riba

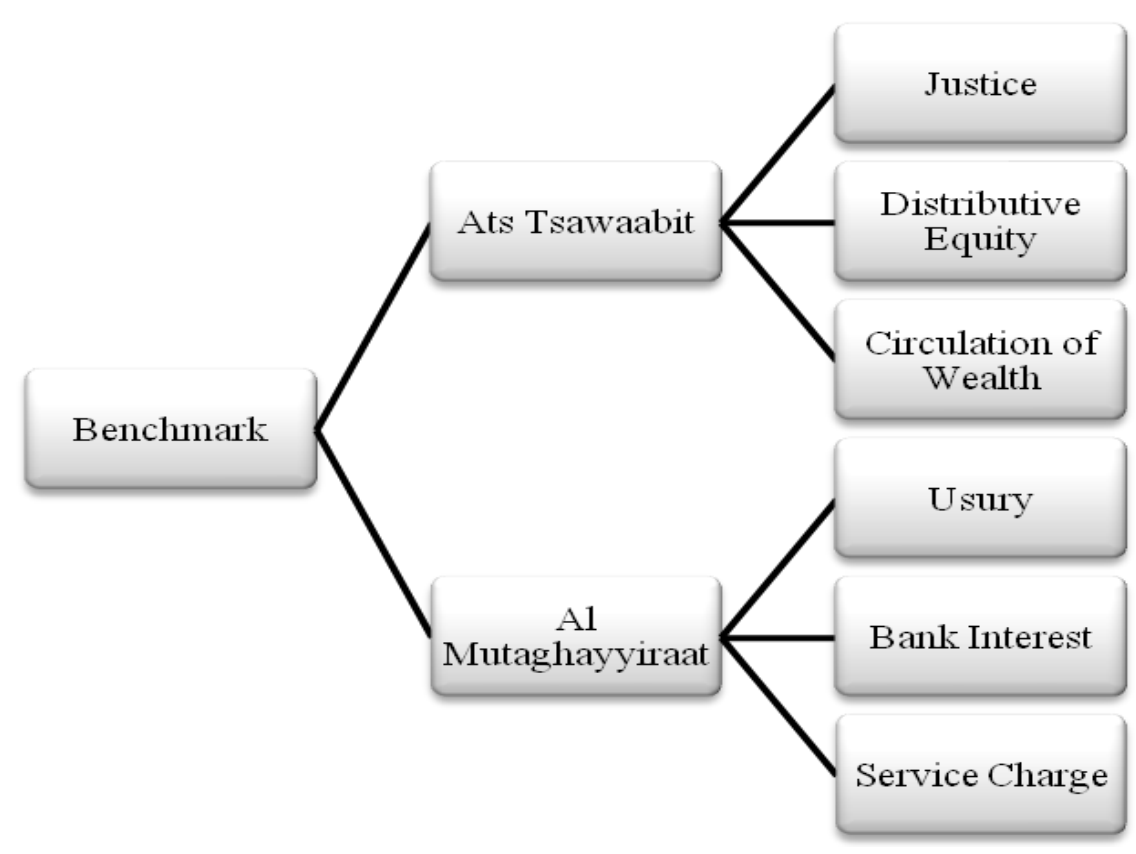

Sumber: Mustafa Omar Mohammed, 2011

Dia mencoba memberikan gambaran baru tentang 'illah riba yang bersumber dari Q.S Ar Rum ayat 39 di mana Allah membandingkan riba dengan zakat.Pada praktiknya, riba mentransfer harta kekayaan kaum fakir kepada pemilik modal, sedangkan zakat meningkatkan harta kekayaan negara karena mentransfer harta kekayaan orang kaya kepada kaum fakir sehingga mengurangi ketidakseimbangan pendapatan.

Prinsip utama dari penjabaran ayat diatas adalah perputaran kekayaan dan persamaan distribusi. Dalam konteks riba kemudian ats-Tsawaabit yang ada adalah nilai 
pokok seperti keadilan, kebajikan, kesamaan distribusi dan lainnya yang dapat menentukan apakah sebuah transaksi dapat melibatkan riba atau tidak. Sementara itu, alMutaghayyiraat yang ada adalah definisi operasional dari riba yang berubah sejalan dengan waktu dan tempat.

Menurut Wahbah Zuhaily, bunga itu termasuk riba nasi'ah karena adanya kelebihan uang tanpa imbalan dari pihak penerima dengan menggunakan tenggang waktu. Sifat bunga itu merupakan kelebihan dari pokok utang yang tidak ada imbalan bagi orang yang berpiutang dan sering menjurus kepada sifat berlipat ganda apabila utang tidak dibayar tepat waktu.Komitmen ini berdasarkan pada pengertian dalam Q.S. $2: 278$ 279, 2: 275-276, 3: 130, 4: 29, dan 30: 39. Apalagi setelah MUI, dalam Rakernas di Jakarta Desember 2004, menyatakan fatwanya bahwa bunga bank haram hukumnya sebab bunga bank adalah riba.

\section{d. Ketentuan Penetapan Harga Jual}

Dalam transaksi jual beli, harga memegang peranan penting untuk sebuah produk. Menurut Basu Swastha, harga ialah jumlah uang yang digunakan di dalam pertukaran suatu barang. Sehingga harga dapat didefinisikan sebagai jumlah uang (ditambah beberapa produk kalau mungkin) yang dibutuhkan untuk mendapatkan sejumlah kombinasi dari produk dan pelayanannya. Berdasarkan definisi di atas dapat diketahui bahwa harga yang dibayar oleh pembeli itu sudah termasuk pelayanan yang diberikan oleh penjual (Swastha, 2008: 271).

Dalam ekonomi Islam siapapun boleh berbisnis, namun demikian dia tidak boleh mengambil keuntungan di atas keuntungan normal dengan menjual lebih sedikit barang untuk harga yang lebih tinggi.Konsep harga dalam Islam sedikit banyak merujuk pada penerapan harga yang adil atau thaman al-mithllqimah al-adl (Hoetoro, 2007: 126). Qimah al-adl digunakan oleh Rasulullah SAW dalam mengomentari kompensasi bagi pembebasan budak, di mana budak ini akan menjadi orang yang merdeka dan majikannya tetap memperoleh kompensasi dengan harga yang adil (H.R Sahih Muslim). Digunakan pula oleh Umar bin Khattab dan Ali bin Abi Thalib, ketika menetapkan nilai baru atas diyah, setelah nilai dirham turun sehingga harga-harga naik (Ibn Hambal).

Berdasarkan pandangan Ibnu Taimiyah, adil bagi para pedagang berarti barang-barang dagangan mereka tidak dipaksa untuk dijual pada tingkat harga yang dapat menghilangkan 
keuntungan normal mereka. Harga adil adalah harga yang terjadi secara bebas-kompetitif atau tidak terdistorsi-antara penawaran dan permintaan ('an taradhin minkum) dan selanjutnya akan mendorong para pelaku pasar untuk bersaing dengan sempurna (Islahi, 1997: 85-90).

Seorang ilmuwan bernama Dan Scotus, mengatakan bahwaharga yang adil adalah harga yang dapat mendorong seseorang memenuhi kebutuhan keluarganya secara layak. Ini berarti bahwa harga harus meliputi biaya dan keuntungan yang cukup untuk memenuhi kebutuhan pedagang itu.

Di dunia bisnis ekonomi Islam, margin atau bagi hasil adalah komposisi utama untuk harga yang dilempar kepada konsumen. Sedangkan menurut Muhammad, faktor-faktor yang perlu dipertimbangkan dalam penetapan margin dan bagi hasil antara lain (Muhammad, 2005: 205-206): a) Komposisi pendanaan; b) Tingkat persaingan; c) Resiko pembiayaan; d) Jenis nasabah; e) Kondisi perekonomian; f) Tingkat keuntungan yang diharapkan bank.

Menurut Bank Indonesia pada suatu transaksi jual beli yang ideal, bank syariah harus dapat menghitung dan memisahkan real costs dan tingkat keuntungan yang diinginkan oleh bank sebagai dasar penetapan margin.Namun demikian, pada kenyataannya margin keuntungan pada transaksi jual beli masih di benchmark terhadap tingkat suku bunga karena belum adanya basis data tentang benchmark biaya perolehan dan handling kelompokkelompok komoditas yang akurat sebagai indikator penetapan margin (Buchori, 2004: 51-52).

Penetapan margin keuntungan pembiayaan berdasarkan rekomendasi dari tim ALCO (Asset Liabilities Committe) Bank Syariah, dengan mempertimbangkan beberapa hal berikut (Karim, 2009: 253-254):

1) Direct Competitor's Market Rate (DCMR), yaitu tingkat margin keuntungan rata-rata perbankan syariah yang ditetapkan dalam ALCO sebagai competitor langsung terdekat.

2) Indirect Competitor's Market Rate (ICMR), yaitu tingkat suku bunga rata-rata perbankan konvensional, atau tingkat rata-rata suku bunga beberapa bank konvensional yang dalam rapat ALCO ditetapkan sebagai kelompok competitor tidak langsung, atau tingkat rata-rata suku bunga bank konvensional tertentu yang dalam rapat ALCO ditetapkan sebagai kelompok competitor tidak langsung yang terdekat. 
3) Expected Competitive Return for Investors (ECRI), yaitu biaya yang dikeluarkan oleh bank yang langsung terkait dengan upaya untuk memperoleh dana pihak ketiga.

4) Overhead cost, yaitu biaya yang dikeluarkan oleh bank yang tidak langsung terkait dengan upaya untuk memperoleh dana pihak ketiga.

Beberapa metode penentuan return pembiayaan adalah sebagai berikut:

- Mark up pricing, yang menjadikan biaya produksi sebagai komponen utamanya

- Target return pricing, yaitu penentuan harga jual produk yang bertujuan mendapat tingkat return atas besarnya modal yang di investasikan. Dalam bahasan keuangan dikenal dengan Return on Investment (ROI).

- Perceived value pricing, yaitu penentuan harga dengan tidak menggunakan variable harga sebagai dasar harga jual. Harga jual didasarkan pada harga pokok pesaing di mana perusahaan melakukan penambahan atau perbaikan unit untuk meningkatkan kepuasan pembeli.

- Value pricing, yaitu kebijakan harga yang kompetitif atas barang yang berkualitas tinggi.

- Going rate pricing, yaitu kebijakan penentuan harga dengan menggunakan tingkat suku bunga pasar sebagai rujukan (benchmark).

Penentuan harga dalam pembiayaan di lembaga keuangan syariah sekarang ini lazimnya menggunakan metode going rate pricing, Adapun alasannya karena lembaga keuangan syariah berkompetisi dengan bank konvensional.Disamping itu mereka juga berkeinginan untuk mendapatkan nasabah yang bersifat floating customer.

Meskipun demikian penentuan harga jual pada produk bank syariah harus memperhatikan ketentuan-ketentuan yang dibenarkan menurut syariah. Oleh karena itu, metode penentuan harga jual berdasarkan pada target return pricing maupun mark up pricing dapat digunakan dengan melakukan modifikasi (Muhammad, 20011: 137-138).

1) Penerapan target return pricing untuk pembiayaan syariah

Lembaga keuangan syariah beroperasi dengan tidak menggunakan bunga.Mekanisme operasional dalam memperoleh pendapatan dapat dihasilkan berdasarkan klasifikasi akad, yaitu akad yang menghasilkan keuntungan secara pasti (natural certainty contract), dan akad yang menghasilkan keuntungan yang tidak pasti (natural uncertainty contract). 
Jika pembiayaan yang dilakukan dengan akad NCC, maka metode yang digunakan adalah required profit rate (rpr).

$$
r p r=n . v
$$

di mana $\mathrm{n}=$ tingkat keuntungan dalam transaksi tunai

$$
\mathrm{v}=\text { jumlah transaksi dalam satu periode }
$$

Sedangkan jika pembiayaan dilakukan dengan akad NUC, maka metode yang digunakan adalah expected profit rate (epr). Di mana epr diperoleh berdasarkan;

- Tingkat keuntungan rata-rata pada industry sejenis

- Pertumbuhan ekonomi

- Dihitung dari nilai rpr yang berlaku di bank yang bersangkutan

Perhitungannya yaitu:

Nisbah bank = eprlexpected return bisnis yang dibiayai $\mathrm{x} 100 \%$

Actual return bank= nisbah bank + actual return bisnis

2) Penerapan mark up pricing dalam pembiayaan syariah

Metode ini hanya tepat digunakan untuk pembiayaan yang sumber dananya dari restricted investment account (RIA) atau mudharabah muqayyadah. Hal ini karena akad mudharabah muqayyadahadalah akad di mana pemilik dana menuntut adanya kepastian hasil dari modal yang diinvestasikan.

Rumusannya adalah sebagai berikut;

Harga jual bank = harga beli bank + (waktu x cost recovery) + keuntungan

Cost recovery $\quad=$ (pembiayaan/estimasi total pembiayaan $) \mathrm{x}$ estimasi biaya operasional 1 tahun

Mark $u$ p/profit margin = persentase $\mathrm{x}$ pembiayaan

Margin dalam $\%=$ cost recovery + keuntunganx $100 \%$

Harga barang di toko

Cost recovery adalah bagian dari estimasi biaya operasi bank syariah yang dibebankan kepada harga beli/total pmbiayaan.

\section{Metode}


Penelitian yang dilakukan adalah penelitian lapangan (field research) dengan menggunakan desain kualitatif agar peneliti dapat mengamati pelaksanaan transaksi murabahah dan mengetahui metode penentuan harga produk murabahah yang diterapkan di BMT RAMA Salatiga secara komprehensif dan mendalam. Sedangkan sifat penelitian ini adalah deskriptif dengan pendekatan yuridis-normatif dan sosiologis karena ingin mengungkap dan selanjutnya menjelaskan tentang pelaksanaan transaksi murabahah beserta kelengkapannya serta tidak dimaksudkan untuk menguji hipotesis. Dalam penelitian ini peneliti bermaksud untuk mengetahui landasan konseptual dan aplikatif dalam penentuan harga harga jual pada produk murabahah di BMT RAMA Salatiga.

Subjek dalam penelitian ini adalah BMT RAMA Salatiga, sedangkan objek yang diteliti adalah: 1) Bagaimana pelaksanaan transaksi produk murabahah pada BMT RAMA Salatiga; 2) Bagaimana metode dan penerapan penentuan harga jual produk murabahah di BMT RAMA Salatiga ditinjau dari pinsip syariah; 3) Bagaimana kebijakan BMT RAMA Salatiga untuk menjalankan usahanya dalam tinjauan syariah.

Dari subjek tersebut, peneliti mengambil sampel menggunakan cara key person (orang kunci) yaitu manajer BMT RAMA. Selain interview terhadap key person, data penelitian juga diambil dari nasabah yang menggunakan produk murabahah di BMT RAMA Salatiga dan juga DPS (Dewan Pengawas Syariah) untuk melihat bagaimana praktik pengawasan agar secara operasional BMT tetap dalam jalur syariah. Pengambilan sampel nasabah dalam penelitian ini menggunakan teknik Non Random (Non Probability) Sampling.

Dalam penelitian ini, teknik pemeriksaan data menggunakan teknik triangulasi sumber di mana penentuan sample nya menggunakan purposive sampling dengan teknik pengumpulan data menggunakan interview juga menggunakan data sekunder berupa dokumen-dokumen.

Lexy J. Moleong menjelaskan lebih lanjut bahwa, Teknik triangulasi sumber dilakukan dengan cara:

a. Membandingkan data hasil wawancara dengan data dokumen yang berkaitan.

b. Membandingkan data hasil wawancara terhadap subjek penelitian dengan hasil observasi.

c. Membandingkan data dokumentasi yang dibutuhkan dalam penelitian dengan hasil observasi

(Moleong, 2005: 330) 
Setelah data diperoleh maka tahap berikutnya adalah mengolah data atau menganalisis data. Dalam menganalisis data menggunakan non statistik, yaitu analisis deskriptif, artinya dari data yang diperoleh dalam penelitian dilaporkan apa adanya kemudian dianalisis secara deskriptif. Langkah-langkahnya sebagai berikut: reduksi data, klasifikasi data, penafsiran data, display data, dan terakhir adalah pengambilan kesimpulan.

\section{Pembahasan}

Sebagai lembaga keuangan syariah yang memiliki visi sebagai lembaga yang profesional, maka BMT RAMA pun menuangkan aturan-aturan dasarnya dalam sebuah SOP yang berlaku internal maupun eksternal. Hal ini dimaksudkan agar BMT RAMA selalu konsisten dalam jalur syariah. Hal yang sama berlaku pula untuk pembiayaan murabahah. Sebagai sebuah standar dalam pelaksanaan operasional bagi karyawan yang akan mengurusi proses pembiayaan murabahah nasabahnya.

Murabahah yang telah ada sejak BMT RAMA ini berdiri menjadi produk favorit tidak hanya bagi nasabah tapi juga bagi BMT sendiri. Hal ini dipilih karena murabahah termasuk akad natural certainty contracts yang memberikan keuntungan yang pasti. Dari wawancara yang dilakukan oleh penulis kepada Bapak FN selaku manajer BMT, kondisi penyaluran dana sekarang didominasi oleh akad murabahah ini.Selain karena perikatannya hanya berupa jual beli, persyaratan dan proses selama akad berlangsung pun lebih sederhana dibandingkan dengan misalnya akad mudharabah yang menuntut adanya pengawasan yang terus menerus atas usaha yang dilakukan nasabah agar tidak ada kecurangan dalam praktiknya. Bahkan menurut peneliti, ada kecenderungan bahwa setiap nasabah yang ingin mengajukan pembiayaan akan di arahkan ke pembiayaan murabahah. Hal ini peneliti dapatkan dari proses observasi ketika ada nasabah yang datang ke BMT, oleh AO langsung ditawari pembiayaan murabahah, dan karena kebanyakan nasabah belum cukup tahu jenis-jenis produk BMT, maka nasabah mengikuti saja apa yang disarankan pihak BMT.

Berdasarkan wawancara dan hasil observasi yang dilakukan oleh peneliti, BMT RAMA menggunakan akad murabahah dengan metode wakalah. Hal ini dilakukan dengan pertimbangan agar barang-barang yang diajukan oleh nasabah memiliki spesifikasi yang sesuai dengan apa yang diinginkan nasabah, hal ini pun akan lebih mempersingkat waktu dan proses karena tidak 
akan ada komplain dari nasabah terkait ketidakcocokan atas spesifikasi barang. Dalam hal kepraktisan menjadi pertimbangan pula bagi BMT.

Secara skematis dari menyaring dari berbagai sumber informasi dan observasi dokumen, proses murabahah dengan akad wakalah di BMT RAMA bisa digambarkan sebagai berikut;

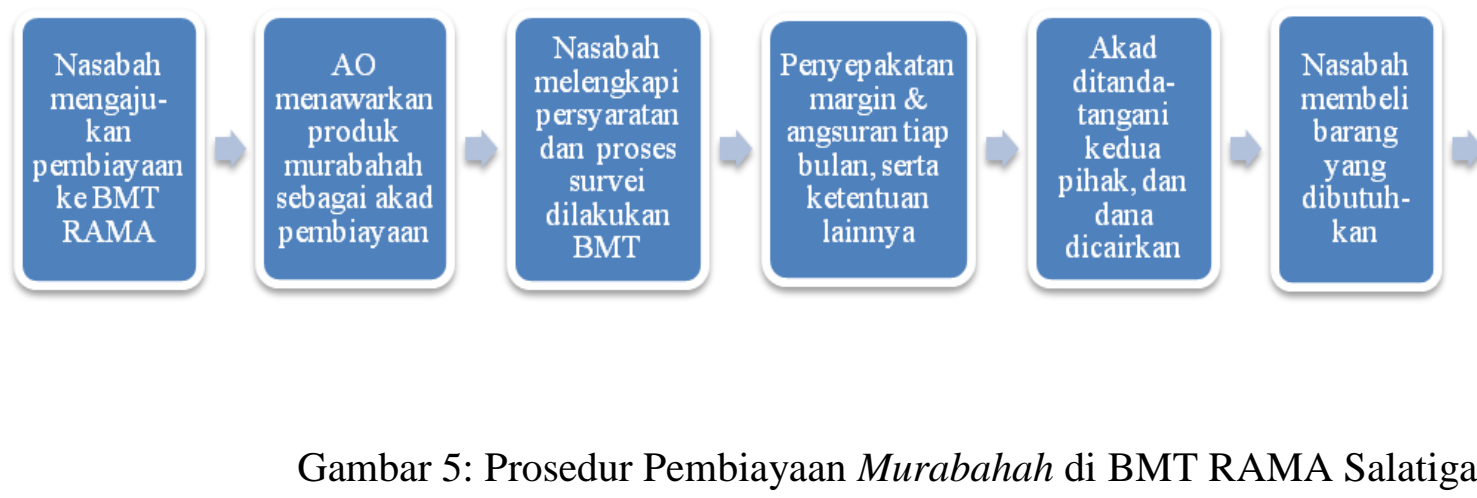

Ada berbagai kalangan yang menggunakan akad murabahah ini. Karena lokasinya yang berada di sentral pasar, para pedagang cukup mendominasi pengguna pembiayaan murabahah ini selain juga nasabah dengan latar belakang pekerjaan guru, PNS, distributor, kontraktor. Mulai nominal pembiayaan Rp. 300.000,- hingga Rp. 100.000.000,- pernah dilayani oleh BMT RAMA. Sedangkan produk-produk yang diajukan juga berbagai macam mulai dari berbagai barang dagangan, laptop, motor, mobil, dan lain-lain.

Dari wawancara yang dilakukan peneliti kepada Bapak FN selaku manajer BMT RAMA, diketahui bahwa bagi nasabah yang baru, maka setiap ada yang disetujui pembiayaannya, mereka otomatis menjadi anggota BMT RAMA. Begitu dana turun, pengelolaannya akan diserahkan kepada nasabah. Asumsinya, BMT mempercayai nasabah bahwa penggunaan dananya akan dimanfaatkan sesuai dengan kebutuhan yang diajukan nasabah kepada BMT. Baru kemudian nasabah berkewajiban mengangsur kepada BMT sesuai dengan nominal yang disepakati sampai kewajiban itu selesai, yang terdiri dari angsuran pokok, margin, dan simpanan wajib sebagai konsekuensi menjadi anggota BMT. Begitu selesai, nasabah memiliki alternatif untuk meneruskan keanggotaannya di BMT atau menyelesaikannya, dengan catatan bahwa simpanan pokok dan simpanan wajibnya dapat diambil. Ini adalah salah satu strategi dari BMT untuk memperbanyak anggota. 
Dalam murabahah, ada beberapa ketentuan yang harus dilaksanakan oleh BMT. Berkaitan dengan prosedur pembiayaan murabahah, dari 6 responden yang diwawancara, memberikan 5 jawaban berbeda untuk poin ini. Prosedur mulai dari mengisi formulir dan mengumpulkan persyaratan menjadi jawaban yang dipilih oleh dua responden, yaitu sebanyak $33,33 \%$ sesuai dari hasil reduksi data yang dilakukan peneliti. Sedangkan yang lain memiliki pendapat yang berbeda-beda. Mengenai persyaratan yang harus dipenuhi oleh nasabah, informasi yang didapat dari manajer BMT RAMA sudah menerapkan hal yang sesuai dengan SOP KJKS poin legalitas pembiayaan. Teknik pengecekan triangulasi yang dilakukan oleh peneliti pun juga menghasilkan hal yang sama. Dalam SOP KJKS, dijelaskan bahwa untuk pembiayaan perseorangan, persyaratan yang harus dipenuhi adalah foto copy KTP suami-istri, Foto copy kartu keluarga, foto copy rekening listrik/telpon/PAM, dan bagi usaha yang sudah memiliki SIUP/TDP/NPWP juga wajib menyerahkan salinannya.

Dalam upayanya untuk menjadi lembaga keuangan yang berkembang, BMT RAMA selalu melakukan evaluasi dalam kinerjanya. Salah satunya berkenaan dengan margin yang didapat dari transaksi jual beli murabahah. dalam penjelasan yang diberikan manajer BMT kepada penulis, didapatkan bahwa kinerja tahun sebelumnya menjadi pokok dari penyusunan segala kebijakan, tak terkecuali perkara penetapan harga jual.

Lebih khusus untuk murabahah, Bapak FN menjelaskan bahwa penentuan harganya langsung dari pihak supplier. Sedangkan BMT lebih pada penghitungan margin dari dana pembiayaan yang diturunkan. Hal ini karena BMT menerapkan wakalah dalam akad murabahah-nya, di mana BMT hanya memiliki peran sampai ketika dana diturunkan kepada nasabah. Margin itu sendiri didapatkan dari komposisi cost of fund, biaya yang harus dikeluarkan BMT untuk survey dan semacamnya (overhead cost), resiko pembiayaan, target laba, serta kompetisi dengan lembaga keuangan lain di mana pesaing utama bagi BMT RAMA untuk sekarang adalah bank-bank plecit dan BRI. Pertimbangan ini diambil agar BMT tetap bisa bertahan tapi juga tidak memberatkan nasabah-nasabahnya sehingga mereka akan setia menjadi nasabah BMT RAMA. Suhardjono dalam bukunya menjelaskan bahwa,

Cost of fund adalah seluruh biaya yang dikeluarkan untuk mendapatkan dana, yang terdiri dari bunga simpanan, biaya promosi dan biaya hadiah (Suhardjono: 303).

Lebih lanjut dijelaskan oleh manajer BMT, bahwa BMT harus realistis atas perkembangan sektor keuangan diluar sana, bahwa pesaing mereka juga memiliki strategi- 
strategi untuk menarik nasabah, bisa dalam bentuk persentase bunga yang lebih rendah, atau mudahnya prosedur pencairan dana. Karena itulah margin yang ditetapkan BMT sebesar 1,5\%-2\% pun harus menyesuaikan kondisi. Dalam penentuan persentase margin, AO BMT RAMA menanyakan kepada nasabah kesanggupan atas persentase tersebut. Disana ada tawar menawar antara pihak BMT dan nasabah. Namun jika ada nasabah yang tidak bisa memberikan margin minimal 1,5\%, maka BMT tidak bisa menerima pengajuan pembiayaan karena hal itu dianggap tidak akan bisa menutupi segala pengeluaran BMT.Beberapa responden menyatakan bahwa tingkat margin hanya disosialisasikan oleh BMT tanpa membuka ruang tawar menawar, sedangkan sebagian lagi menjawab bahwa BMT memberikan ruang tawaran atas margin yang mereka ajukan.

Menarik untuk diperdalam tentang penggunaan cost of fund sebagai salah satu komposisi dari penetapan margin di BMT RAMA. Cost of fund (COF) adalah biaya yang dikeluarkan oleh bank atas dana nasabah yang ditempatkan, yaitu berupa persentase bunga yang diberikan kepada nasabah setiap bulannya, untuk setiap rekening yang dimiliki oleh nasabah. COF inilah yang kemudian menjadi salah satu elemen saat bank menentukan kebijakan besaran suku atas pembiayaan yang dikeluarkan bank. Untuk itu BMT harus selalu dalam kondisi untung agar mampu memenuhi cost of fund tersebut. Penentuan cost of fund sendiri ditentukan salah satunya adalah dari besaran SBI (Sertifikat Bank Indonesia) yang dikeluarkan oleh BI. Karena BI pun juga berkepentingan untuk mengatur likuiditas yang beredar ditengah masyarakat, karena dengan instrumen inilah BI bisa mengendalikan tingkat inflasi (Abduh, 2011).

Sama halnya dengan apa yang ditulis Muhammad Abduh, di BMT RAMA pun juga terjadi. Sebagai dampak langsung atas digunakannya flukuasi tingkat suku bunga yang berlaku dipasar dan kepastian bagi hasil kepada pemilik modal penyertaan dan nasabah penyimpan, maka akan ada beban marjinal minimal yang tidak dapat ditawar lagi oleh calon nasabah kepada pihak bank, dalam hal ini BMT. Konsep seperti ini dikenal sebagai cost of fund pada perbankan konvensional, di mana operasional bank lebih dominan bertumpu pada selisih keuntungan.

Salah satu yang menjadi dasar kesalahan sehingga menerapkan konsep cost of fund adalah pemahaman yang keliru bahwa sebuah BMT harus selalu mendapatkan keuntungan. Selain akan memberatkan nasabah pembiayaan, menjanjikan bahwa suatu usaha akan selalu 
untung juga dilarang dalam Islam. Sebab adakalanya suatu usaha itu mendapatkan keuntungan, namun adakalanya juga menderita kerugian. Yang paling utama adalah berpegang pada prinsip tidak melakukan judi, penipuan, zalim serta terbebas dari riba.

Oleh karena itu, semakin terlihat bahwa dari sisi praktik penentuan harga jual barang pada akad murabahah masih timpang dengan aturan Islam. Besar ataupun kecil, para nasabah pembiayaan-khususnya murabahah menerima beban bagi hasil atas keuntungan nasabah penyimpan dan pemilik saham yang seharusnya ditanggung oleh bank baik ketika untung ataupun rugi.Hal ini menunjukkan dilanggarnya prinsip al kharaj bi al dhaman (hasil usaha muncul bersama biaya) dan prinsip al ghunmu bi al ghurmi (untung muncul bersama resiko). Padahal prinsip-prinsip tersebut merupakan prinsip dasar dalam teori keuangan, yakni prinsip bahwa return selalu beriringan dengan resiko atau return goes along with risk (Karim, 2003: 40).

Masuk dalam pembahasan tentang angsuran. Angsuran yang diterapkan oleh BMT RAMA adalah dengan metode flat rate, karena pertimbangan bahwa akan memudahkan nasabah dalam mengingat beban yang harus diangsur setiap bulannya ke BMT.

Berikut contoh penghitungannya;

Pak Kelik mengajukan pembiayaan untuk pembelian mobil second seharga Rp. 40.000.000,-. Margin keuntungan yang disepakati adalah 2\% selama 12 bulan, maka perhitungannya adalah:

$\begin{array}{rlr}\text { Keuntungan jual beli } & =2 \% \times \text { Rp. } 40.000 .000 & =\text { Rp. } 800.000 \\ & =\text { Rp. } 800.000 \times 12 & =\text { Rp. } 9.600 .000 \\ \text { Harga jual } & =\text { Rp. } 49.600 .000,- & \end{array}$

Akad wakalah dijadikan sebagai pilihan BMT atas pembiayaan murabahah ini. Namun begitu peneliti dalami lebih lanjut, ada yang ganjil dengan prosedur akad wakalah yang digunakan dalam BMT ini. Berdasarkan dokumen-dokumen yang peneliti ketahui, juga observasi dan wawancara kepada manajer dan nasabah, diketahui bahwa nasabah yang seharusnya nantinya akan membeli barang sebagai wakil dari BMT tidak melakukan hal tersebut.

Dalam kajian teori yang telah penulis lakukan, ada beberapa ketentuan yang ini menjadi catatan untuk BMT RAMA. Misalnya tentang akad yang sudah ditandatangani walau barang belum dimiliki atau belum dalam penguasaan oleh BMT. Seharusnya jika akadnya wakalah, 
penandatanganan akad dilakukan setelah nasabah membeli barang, kemudian barang diserahkan ke BMT (karena status nasabah sebagai wakil BMT sudah selesai) barulah akad ditandatangani. Proses yang ada sebelum akad dilakukan adalah hanya menyepakati ketentuan-ketentuan umumnya.

Menjual barang yang tidak dimiliki adalah tindakan yang dilarang syariah karena termasuk bai' al fudhuli. Para ulama klasik telah memberikan alasan secara rinci mengenai pelarangan tersebut. Akan tetapi beberapa ulama modern menunjukkan bahwa konteks jual beli murabahah jenis ini di mana 'belum ada barang' berbeda dengan 'menjual tanpa kepemilikan barang' (Antonio: 104).

Dalam ketentuan pertama butir 9 fatwa DSN No. 4/DSN-MUI/IV/2000 disebutkan bahwa “jika bank hendak mewakilkan kepada nasabah untuk membeli barang dari pihak ketiga, akad jual beli murabahah harus dilakukan setelah barang dibeli, jadi secara prinsip barang tersebut menjadi milik bank". Barulah kemudian barang itu diserahkan kepada nasabah. Jadi jelas bahwa tidak diperkenankan melakukan akad jual beli jika memang tidak ada barangnya.

Salah satu resiko yang akan ditanggung oleh BMT terkait pembiayaan murabahah adalah resiko yang timbul dari barang yang dijual kepada nasabah. Ketika membeli barang yang diminta oleh nasabahnya, maka secara teoritis BMT menanggung resiko kehilangan atau kerusakan pada barang-barang tersebut dari saat pembelian sampai diserahkan kepada nasabah. Padahal dalam Islam, konsumen berhak menolak barang jual beli yang memang cacat atau tidak sesuai dengan yang diminta. Konsep ini dikenal dengan istilah khiyar, yaitu hak yang dimiliki orang yang melakukan kontrak untuk memilih yang terbaik diantara dua hal, melanjutkan akad atau membatalkan akad. Hikmah disyariatkannya khiyar adalah membuktikan dan mempertegas adanya kerelaan dari pihak yang terikat dalam perjanjian dalam rangka menghindari perselisihan. Oleh karena itu, BMT bisa saja menetapkan biaya asuransi dalam klausul akad yang dibuat dengan nasabah.

Dalam peristiwa di BMT RAMA, seolah-olah BMT tidak ingin direpotkan dengan proses nasabah mendapatkan barang yang dia butuhkan. Hal ini sesuai pendapat Bapak AD bahwa BMT mempercayakan sepenuhnya penggunaan dana yang dicairkan oleh BMT tanpa ada proses pengawalan atau pengawasan terhadap dana tersebut. Hal ini menjadi catatan tambahan bagi BMT RAMA karena jika kondisinya memang begitu adanya, hal ini tidak jauh beda dengan kredit-kredit di bank konvensional. Di bank konvensional hanya tahu penyerahan dana saja tanpa 
adanya pengecekan atas penggunaan dana yang diterima nasabah. Dalam lembaga keuangan konvensional disebut sebagai kredit investasi. Sikap jujur yang seharusnya menjadi bagian dari edukasi oleh BMT kepada nasabah harus diperketat melalui pendampingan, karena sangat memungkinkan dana tersebut digunakan untuk hal-hal yang tidak sesuai syariah.

Praktik tersebut jelas secara aturan telah melanggar SOP KJKS, fatwa DSN No. 04/DSNMUI/IV/2000 butir 9 tentang penguasaan barang yang secara prinsip harus menjadi milik bank dan semua hal yang mengatur tentang murabahah. Jelas disebutkan disana bahwa persyaratan pembiayaan murabahah yang berkenaan dengan obyek yang diperjualbeikan adalah bahwa barang merupakan hak milik penuh yang berakad. Alasan agar lebih sederhana prosesnya atau agar kedua pihak yaitu pihak BMT dan pihak nasabah tidak repot serta agar barang sesuai spesifikasi yang diinginkan oleh nasabah, tidak bisa dijadikan alasan untuk merubah alur yang memang seharusnya ada. Jika BMT masih melakukan seperti sekarang ini, maka hal itu tergolong jual beli gharar karena dalam jual-beli tersebut barang tidak bisa diserahkan kepada nasabah, bahkan termasuk jual beli fasid. Hal ini masih sama persis dengan pemberian kredit di lembaga keuangan konvensional.

BMT RAMA harus lebih berani untuk mengambil risiko pembiayaan karena di dalam Fikih Muamalat keuntungan boleh diperoleh dengan adanya risk sharing dan juga investasi yang bersifat bagi hasil dan partnership sehingga jelaslah besarnya potensi dan peranan BMT terhadap pengembangan ekonomi terutama pada sektor riil.

Dalam menjalankan usahanya, BMT RAMA diawasi oleh DPS dan Pengawas Manajemen. Namun sejauh apa yang digali oleh peneliti, peran mereka masih sangat terbatas. Keterlibatan dalam pengawasan yang hanya dua kali dalam setahun, masih sangat jauh dari kebutuhan yang seharusnya. Bahkan dari wawancara yang dilakukan oleh peneliti, tidak ada tindakan yang tergambar dari aktivitas pengawas jika ada pelanggaran yang dilakukan, baik secara manajerial maupun atas prinsip-prinsip syariahnya.

Pola komunikasi yang dibangun antara BMT dan DPS yang begitu terbatas, sangat memungkinkan bahwa secara pelaksanaan sangat rawan akan adanya penyimpangan. Sedangkan pengawas manajemen dan DPS pun hanya bertanggungjawab pada anggota melalui RAT.

Dalam hal pengawasan eksternal, BMT RAMA juga di audit oleh auditor eksternal dan dari Dinas Koperasi. Auditor eksternal lebih banyak mengkaji tentang bagian keuangan, sedangkan Dinas Koperasi mengkaji tentang manajemen dan perangkat yang dibuat BMT, 
seperti visi misi, SOP, prosedur, likuiditas, aturan-aturan pembiayaan, dan sebagainya. Dari keduanya tidak ada yang mensupervisi tentang pelaksanaan kegiatan BMT dari sisi kesyariahan.

\section{Penutup}

Kesimpulan tentang pelaksanaan pembiayaan murabahah beserta penetapan harga jual di BMT RAMA Salatiga adalah sebagai berikut:

1. BMT RAMA menggunakan akad murabahah dengan wakalah sebagai akad untuk pembiayaan-pembiayaan yang diajukan nasabah. Dalam pelaksanaannya, akad murabahah yang dipraktikkan BMT RAMA tidak sesuai dengan prosedur dalam SOP KJKS dan fatwa DSN No. 04/DSN-MUI/IV/2000 karena akad jual beli dilakukan sebelum barang secara prinsip dalam penguasaan BMT atau tidak dimiliki oleh BMT.

2. Dalam hal penetapan harga jual produk murabahah, BMT RAMA menggunakan faktor-faktor berikut sebagai pertimbangannya; resiko pembiayaan, cost of fund, biaya operasional, target laba tahun ini, target pembiayaan tahun ini, dan posisi persaingan. Dalam unsurcost of funddapat dijelaskan bahwa BMT RAMA memang menggunakan faktor bunga sebagai komposisi harga jual produk murabahah mereka. Dan hal ini bertentangan dengan fatwa MUI No. 1 tahun 2004 tentang pengharaman bunga juga fatwa DSN No. 04/DSN-MUI/IV/2000 butir satu. Ditambah dengan biaya administrasi sebesar 3\% yang dibebankan pada nasabah, yang dalam hemat penulis, hal ini termasuk mark up yang tidak rasional yang akan menjadi dana syubhat bagi arus keuangan BMT RAMA.

3. Dalam usaha menghindari bunga bank sebagai hal yang jelas ribawi, BMT RAMA belum memiliki sikap tegas dan jelas. Dari pengawasan DPS pun tidak cukup optimal dengan hanya dilibatkan dua kali dalam setahun dan hanya bersifat koordinasi. Selain itu, tidak ada pengawasan dari pihak manapun tentang aktivitas syariah di BMT.

\section{Daftar Pustaka}

Akhbarudin. 2007. Implementasi Murabahah pada BMT Amanah di Kecamatan Galur Kabupaten Kulonprogo. Yogyakarta: MSI UII.

Antonio, Muhammad Syafi'i. 1999. Bank Syariah bagi Bankir \& Praktisi Keuangan. Jakarta: Bank Indonesia kerjasama Tazkia Institute.

Asymawi, Muhammad Sa'id. 2009. Riba wal Faidah alih bahasa Khilmi Dzulqornain, Tugas Resume Fikih Muamalah, Yogyakarta. 
Buchori, Ahmad, dkk. 2004. Standarisasi Akad Perbankan Syariah. Jakarta: Bank Indonesia.

Departemen Agama RI. 2006. Al-Quran dan Terjemahnya. Bandung: CV Penerbit Diponegoro.

Firmansyah. 2007. Evaluasi Penerapan Metode Penetapa Harga Jual Beli Murabahah (Studi Kasus pada BMT Berkah Madani. Jakarta: STEI SEBI.

Harun, Ubay. 2006. Murabahahdalam Perspektif Fikih dan Sistem Perbankan Islam, Yogyakarta: Hukum Islam.

http://puskopsyahjogja.blogspot.com/, diakses pada 3 Oktober 2011.

http://www.smecda.com/Files/Dep_Pembiayaan/8_SOP_KJKS.pdf hal. 86, diakses pada 5 Oktober 2011

http://www.pemkot-salatiga.go.id/Data/Info/Bappeda/ProfilDaerahSalatiga2010.pdf, diakses pada 11 September 2011.

http://www.ruf.rice.edu/ elgamal, diakses pada 1 September 2011.

http://imagesstaticians81.multiply.com, diakses pada 1 September 2011.

http://mediamuslim.blogdetik.com/pabochech/3/hukum-bunga-bank-tidak-haram/, diakses pada tanggal 3 Oktober 2011.

Islahi, A.A.1997. Konsepsi Ekonomi Ibnu Taimiyah. Surabaya: PT Bina Ilmu.

Karim, Adhiwarman A. 2006. Bank Islam Analisis Fikih dan Keuangan, Cet.3. Jakarta: PT Raja Grafindo.

Kasmir. 2003. Manajemen Perbankan. Jakarta:PT Raja Grafindo Persada.

Kusmiyati, Asmi Nur Siwi. 2007. Risiko Akad dalam Pembiayaan Murabahah pada BMT di Yogyakarta (dari Teori ke Terapan). Yogyakarta: La Riba.

Lewis, Mervyn K dan Latifa M Algaoud. 2005. Islamic Banking, alih bahasa Burhan Wirasubrata, Cet. II. Jakarta: PT Serambi Ilmu Semesta.

Madjid, Baihaqi Abd. (Ed). 2000. Paradigma Baru Ekonomi Kerakyatan Sistim Syariah: Perjalanan Gagasan dan Gerakan BMT. Jakarta: PINBUK.

Moleong, Lexy J. 2005. Metode Penelitian Kualitatif. Bandung: PT Remaja Rosdakarya.

Muhammad. 2005. Manajemen Pembiayaan Bank Syariah. Yogyakarta: UPP AMP YKPN.

Muhammad. 2005. Manajemen Dana Bank Syariah. Yogyakarta: Ekonisia.

Muslim. 2007. Prediksi Sengketa Pembiayaan Murabahah. Yogyakarta: MSI UII. 
PINBUK. Pedoman Cara Pembentukan BMT. Jakarta: PT. Bina Usaha Indonesia.

Praja, Juhaya S. 1998. Filsafat Hukum Islam.Bandung: LPPM-UIB.

Pujiastuti, Umi. 2000. Pendirian dan Pengelolaan BMT di Lingkungan Pondok Pesantren. Jakarta: Depag.

Rahmawaty, Anita. 2007. Ekonomi Syariah: Tinjauan Kritis Produk Murabahah dalam Perbankan Syariah di Indonesia Yogyakarta: La Riba.

Ridwan, Muhammad. 2003. Manajemen Baitul- Maal wa Tamwil (BMT). Yogyakarta, UII Press.

Rivai, Veithzal dan Andi Buchari. 2009. Islamic Econimics. Jakarta: PT Bumi Aksara.

Saeed, Abdullah. 2003. Bank Islam dan Bunga, Studi kritis dan Interpretasi Kontemporer tentang Riba dan Bunga, Terj. Muhammad Ufuqul Mubin, et. al, Cet. 1. Yogyakarta:Pustaka Pelajar.

Schacht, Joseph. 1986. The Encyklopaedia of Islam. Leiden: E. J. Brill.

Sjahdeini, Sutan Remi. 1999. Perbankan Islam dan Kedudukannya dalam Tata Hukum Perbankan Indonesia. Jakarta:Pustaka Utama Grafiti.

Soedrajat, Setyo. 2004. Manajemen Pemasaran Jasa Bank. Jakarta: PT Ikral Mandiri Abadi.

Sudarsono, Heri. 2004. Bank dan Lembaga Keuangan Syariah Deskripsi dan Ilustrasi, Cet. 2, Yogyakart: Ekonisia.

Sugiyono. 2001. Metode Penelitian Bisnis. Bandung: CV Alfabeta.

Swastha, Basu dan Irawan. 2008. Manajemen Pemasaran, Modern. Yogyakarta: Liberty.

Tim Counterpart PT Bank Muamalat Indonesia. 1999. Fikih Muamalat Perbankan Syariah, Kapita Selekta Al Fiqhu Al Islam Wa 'Adillatuhu oleh Wahbah Zuhaili. Jakarta.

Tim Pengembangan Perbankan Syariah Institut Bankir Indonesia. 2004. Bank Syariah: Konsep, Produk dan Implementasi Operasional. Jakarta: Djambatan.

Tojibi, Wildan. 2007. Tinjauan Yuridis terhadap Transaksi Murabahah pada Bank Muamalat Indonesia Cabang Yogyakarta. Yogyakarta: MSI UII.

Wiroso. 2005. Jual beli Murobahah. Yogyakarta: UII Press.

Zuhaili, Wahbah. 2006. al-Fiqh al Islam wa Adillatuh. Terj. Ubay Harun. Yogyakarta: Hukum Islam.

\section{Wawancara:}


Wawancara dengan Bapak AD selaku Account Officer (AO) BMT Rama Salatiga, pada tanggal 11 November 2011.

Wawancara dengan Bapak FN selaku Manajer BMT Rama Salatiga, pada tanggal 1 Desember 2011. 